\title{
Sustainable Management of KCCA Mpererwe Landfill: History, present, future possibilities and solutions. A qualitative study
}

\author{
${ }^{1}$ Nabukeera Madinah, ${ }^{2}$ Ali Boerhannoeddin, ${ }^{3}$ Raja Noriza Binti Raja Ariffin \\ ${ }^{1}$ Management Faculty , P.O.Box 2555 Mbale Uganda, Islamic University In Uganda \\ ${ }^{2}$ Department of Administrative studies and Politics Faculty of Economics and Administration Kuala Lumpur \\ P.O. box 50603 Malaysia \\ ${ }^{3}$ Department of Administrative studies and Politics Faculty of Economics and Administration Kuala Lumpur \\ P.O. box 50603 Malaysia
}

\begin{abstract}
Approximately 1500 tonnes are dumped at Kitezi landfill presently in Uganda, due to increased daily generation of solid waste. Although this state of affairs calls for improvement of the practices at the landfill in a sustainable manner to safeguard the environment and uphold public health, the required technology for the landfill is yet to be attained. The aim of this paper is to ascertain and assess the growth and tendencies in landfil utilization in Uganda. In 1970s management of solid was characterized by the use of the traditional open dumping sites normally found in the suburbs of the city, an approach that was suitable since the population was still low. The period from 1986 embraced a decentralized system of management that was accompanied with rapid construction of residential structures and a reduction in spaces for open dumping. This called for a more organized system for solid waste management. Thus waste management became a responsibility of the five divisions under Kampala Capital City Authority. In early1990s, outsourcing of solid waste management services in all divisions of KCCA was witnessed and in 1996 the first sanitary landfill was launched at Kitezi as the only engineered landfill (called 'Kitezi Landfill') for municipal waste. In 2005 the landfill became a nuisance because of bad odour, vermin and this was made worse by scavengers who scattered waste in the neighborhood. In 1999 the National environment regulation for Uganda was implemented for municipal waste to enable cleaner production methods, licenses and to devolve power for inspecting the environment. Although implementation of the regulations is yet to yield modest results, it is clear that it was big step towards a positive foundation establishing a sustainable disposal and solid waste management system in Uganda.
\end{abstract}

Key words: Landfill Sustainability, Municipal Solid Waste, Backlogs, Privatization, Legal framework, Kampala Capital City Authority, Uganda

\section{Background}

Quite a number of factors affect the process and systems of waste management in any country. Consequently recognizing the impediments among others is an indispensable milestone in the right direction of maintainable practices. When societies started settling together in groups, management of solid waste became a concern in that particular area. Solid waste increased as the population grew and in such an instance, it became paramount to put in place a proper system for its management . Originally, managing solid waste was applied merely by collecting it from residential areas and work places to dump it in the far inaccessible places where the smell would not turn into public nuisance commonly termed as "madding crowd". The aims of the old dumping methods were for improving community health and sanitation. In spite of this, globalization trends highlighted that the longstanding methods of disposal were inadequate after the discovery of related environmental and health related problems caused as a result of emissions of leachate and gas from the dumping sites into surface and underground water due to inappropriate and unmaintainable dumping habits. Therefore it became critical for poor and developing countries to workout approaches in order to enhance the perception of managing solid waste (Agamuthu, Khidzir, \& Hamid, 2009).Globally, the 3Rs (Reduce, Reuse and Recycle) are the main concepts that are being fronted to promote sustainable solid waste management or Zero Waste Management ,(Agamuthu et al., 2009).

Nevertheless the unmaintainable dumping sites are still essential in waste management due to their economic value since poor developing nations lack enough funds to attain zero waste or procure recommended technology. Hence landfills in developing countries have reached an unsustainable point (adewale (Adewale, 2011; Nguyen, 2011).

A number of effects have been identified from the inappropriate activities at the landfill i.e., impact of landfilling and composting on green gas emissions (Lou \& Nair, 2009)), effects of solid waste treatment on public health and environmental safety (Hamer, 2003), landfill management, leachate generation in Australia (Scott, Beydoun, Amal, Low, \& Cattle, 2005), ground water contamination (Fauziah S.H., 2005). Nevertheless it's serious that landfills should be managed in a sustainable manner to reduce on the impending threats. The 
concept of landfill sustainability is actually a campaign to ensure that landfills are friendly and hazard free to fellow citizens and societies neighboring them hence preventing costs that would have accrued from the risks and protecting the environment. Today landfill maintenance activities are a potential wealth since they have ability to generate gas as a fuel (Uganda, 2011; UNEP, 2011).

The annual municipal waste generation of Uganda is up to 350.975 .38 tonnes (Government, 2013) which calls for proven cost effective processes in managing it while at the same time giving priority to ecological issues. However, the lack of a combined system in municipal solid waste management resulted into divisions under KCCA to observe an increase in dumping, Kampala Central 64,171, Kawempe 37,039, Lubaga 41,514, Makindye 30,134, and Nakawa 38,813 tonnes in financial year 2012-13. It is estimated that $65 \%$ of the collected waste is directly disposed off to the landfill. Hence landfilling is a means of waste treatment in Uganda.(KCC, 2000).

In Uganda there is high reliance on landfills therefore it becomes necessary for the government to ensure that they are not neglected and that they are managed in a sustainable manner. This manuscript builds on past studies on landfill sustainable management in the world but sets a precedence in Uganda. The History and contemporary rank is discussed as well as forecasting for the prospects.

\section{Municipal solid waste management in Uganda in early (1970s)}

Management of waste entails creation, reducing, categorizing, supervising, handling, treatment, reprocessing and enduring of solid waste while bearing in mind associated factors including cost effectiveness, environmental risks and community fears. Consequently management of waste schemes can only claim optimal performance if they are cost-efficient, effective, environmentally sensitive and friendly to communities where they are established.

\section{Practices of solid waste management in the past}

In Uganda, the emphasis on waste management was visible in the 1990s when the population of Kampala started to increase (UBOS, 1990). At that time, government operations in solid waste were managed by Kampala City Council (herewith called Kampala Capital City Authority) and activities involved sweeping the main roads in the city with ordinary local made brooms, collection of swept dust in the skips or collection point and burning it. The skips were then transported to distant dumping sites of Lweza and Lubigi which were later closed down. Generally managing waste in Kampala was largely traditional since open dump sites are mainly used to treat waste through burning.

Local authorities in Kampala were fully involved in waste management since 1960s as stipulated in the Urban Authority Act of 1964 and Public Health Act 1964. Although the collection was done on a daily basis, they agreed that the generated waste was overwhelming their capacity to collect due to a number of reasons i.e., absence of solid waste law, lack of equipments, limited funding, failure to implement the bye laws on waste management as passed by the council and central government interference. Waste management in KCC was managed by the Public Health Department (PHD) under the preventive section with accountability extended according to boundaries of each division. KCC was divided into five divisions namely Kampala Central, Lubaga, Makindye, Nakawa and Kawempe and each of these divisions had the responsibility to collect waste in their areas of jurisdiction using garbage trucks and casual workers. While sub counties in the city where seeking for a suitable way forward, their counter parts in the country side still disposed waste through mainly burning and laying it to rest in the ditches since their Local governments hardly provided any sustainable means for disposal. Quite a number of garbage bankers were built for temporary storage of waste, to enable residents dump waste throughout the day until KCC would collect it and transport it to Lweza or Lubigi. However just like skips, these garbage bankers were placed in well to do areas leaving the slums in poor areas uncatered for which in turn encouraged indiscriminate disposal of waste in unwanted places of the city.

The 1980s Uganda had a low population and the Central Government had the responsibility to manage solid waste services though the challenges then were insignificant since, apart from inorganic waste that keeps on changing, the biggest percentage of waste generated was organic waste (to-date the trend is similar but also the quantities generated were low).The period from 1986 embraced a decentralized system of management where solid waste management was a responsibility of the five divisions under KCCA. Under this new system, partial collection was managed by the divisions themselves while the other portion was outsourced to private contractors.

In 1995, the National Environment Act was enacted to support harmonization, observe, control and administer ecological and environmental statutes in the country through a semi-autonomous body called the National Environment Management Authority (NEMA). At the same time, KCCA and other districts in Uganda acted as lead agencies for NEMA on environmental concerns like management of waste to support ensure sustainability activities in solid waste management. 
In 1996 with the help of World Bank, Kitezi sanitary landfill became operational after closing Lweza and Lubigi dumping sites, that were designated sites where the all divisions and the nearby districts where required to dump the waste free of charge. However the landfill was not sustainably managed hence bad odour became a problem to the residents, the leachates polluted the surface and ground water and hence endangered the livestock and at the same time raised health concerns to the surrounding community (Mwiganga \& Kansiime, 2005; NBS, 2013; G. T. NEMA, 2005). With the increased population there was a corresponding increase in the amount of waste generated in the city. At that time it was evident that dumping behaviors had become progressively ineffective.

Consequently, initiatives to enhance municipal, hospital and industrial waste management services were enforced by government nationwide in order to decrease risks related to waste mishandling. This effort resulted into the rebirth of solid waste management regulations and by-laws such as: any organization or person involved in the business of transportation and storage of waste was required to apply for operating license from NEMA and KCC; their operations should be conducted in a manner that does not scatter waste while transporting to the landfill and; transportation of waste should involve approved schedule routes from the collection point to the disposal point. In Rubaga division, the council passed a bye-law on littering waste, for which the penalty charged is 50,000 shillings $(\$ 17.9)$.

In mid-2000, business started booming in the city and as population increased, the small industries started mushrooming in the five divisions. Among the industries that took shape were those that turn waste into wealth. The development did not only turn into a good business but it also instigated the value of plot and property to escalate in city areas. To date, skips are being used in the city especially in places like markets in order to allow vendors to dump waste throughout the day (Mugagga, 2006). The continued use of traditional approaches and skips, lack of a common approach, and failures to manage garbage in Kampala was linked to social, economic as well as political factors that end up determining the governance of solid waste.

Table 1.1: General Wate Composition in Kampala

\begin{tabular}{|l|l|l|l|}
\hline Type of solid waste & $\%(2001)$ & $\%($ June 2006) & $\%(2013)$ \\
\hline Papper \& board & 5.4 & 10.6 & 5.50 \\
\hline Glass & 0.9 & 1.8 & 0.90 \\
\hline Metal & 3.1 & 0.4 & 3.10 \\
\hline Plastic & 1.6 & 11.8 & 1.60 \\
\hline Organics & 83.5 & 73.0 & 73.80 \\
\hline Construction & - & 1.4 & \\
\hline Street Debris & 5.5 & - & 5.50 \\
\hline Tree cutting & - & - & 8 \\
\hline Saw dust & - & - & 1.70 \\
\hline
\end{tabular}

Source: KCC,2006; KCCA, 2013

\section{Privatization in Uganda, 1990-todate}

Waste management in Uganda was privatized just like in many cities in the world (Ahmed \& Ali, 2006; Fauziah \& Agamuthu, 2012; Rabinovitch, 1997; Tukahirwa, Mol, \& Oosterveer, 2010). The main argument was derived from (Hood, 1991, 1995) who emphasized efficiency in public service delivery by enhancing competitiveness which results into improved performance. The argument was later supported by the public choice theories who argued that lack of competition yields inefficiency (Batley, 2001; West, 1976). It was assumed that there are many gains that can be accrued in terms of effectiveness and efficiency if market pressure is exposed in public services. Such arguments where put across in favor of privatization of SWM whose contribution cannot be under estimated in many developing cities around the world (Kassim, 2006).

There are four common known types of privatizing SWM (Baud, Post, \& Furedy, 2004; Post, 2004) i.e., (i) Contracting out, where a district allocates a contract to one or more firms to offer the service through collecting, transporting and disposal, (ii) Concession; where the district allocates a contract to build and operate a waste management facility to assign stations, develop landfill facility, recycle and generate power, (iii) Franchising; where the district gives exclusive license to private company to provide services to specific village, zone or ward and charges the residents fees and in return pays a license fee to the government. The particular district of operation in return monitors, supervises and regulates user charges to avoid over charges and to ensure that the private company contracted is operating within the established standards of license (CointreauLevine, 1994) and (iv) open competition; in this type of arrangement the district registers many private service providers and allows them to compete freely within given jurisdiction of operation. Privatization in Uganda was tangled from within the four different types and open competition is currently being used by KCCA. Contracting out of solid waste management had its intended objectives especially with KCCA;

- Contribution in achieving nationwide growth in policy goals

- Reducing inefficiency in service delivery through reducing public sector involvement in the economy

- Enhancing solid waste management through boosting collection hence increase efficiency in collection rate 
- $\quad$ Reducing government expenditure through savings in administrative costs

The privatization of solid waste management in Kampala increased the number of private players to 150 registered companies (KCCA, 2013) of which many are invisible on ground in terms of operations because they were wrongly awarded the contracts during the KCC regime which was identified as corrupt (Government, 2013). The current administration of KCCA is re-registering private garbage collectors in Kampala with the support of NEMA to eliminate companies that were wrongly registered and streamline garbage collection in the city through zoning to enhance efficiency in solid waste collection.

\section{MAP for Uganda showing Kampala boundary.}

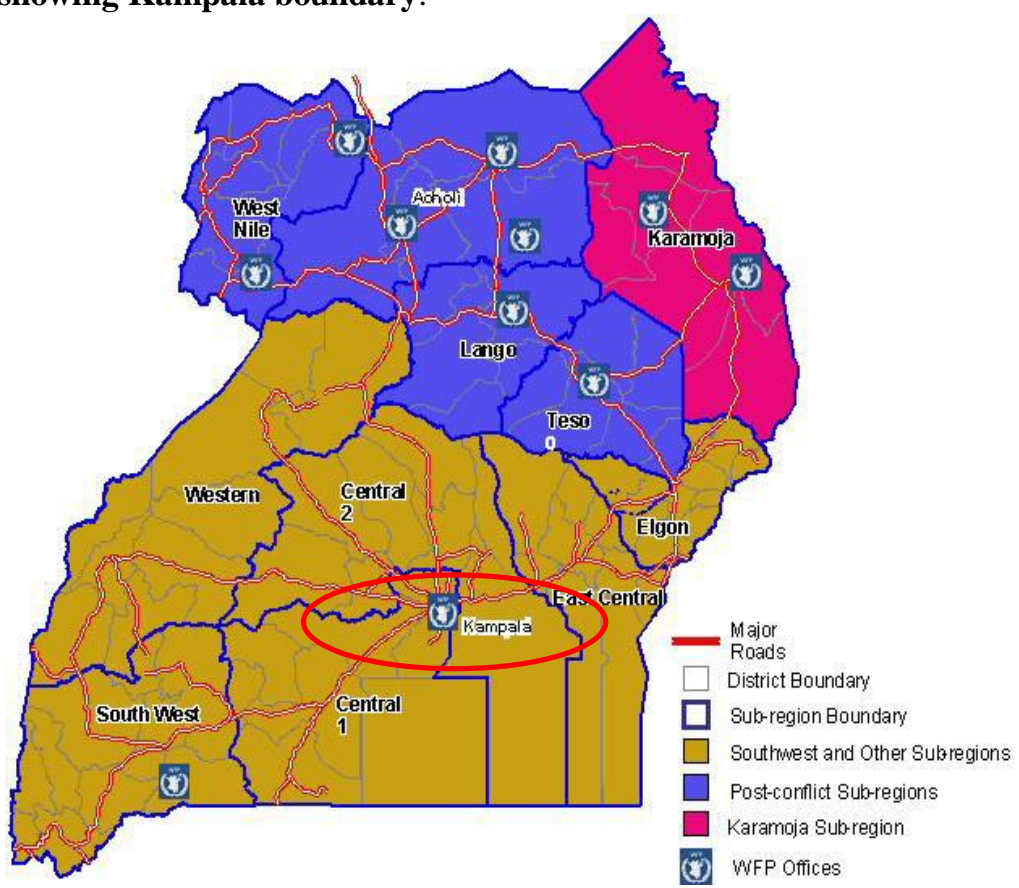

Private sector contribution cannot be under estimated since it comes with improved outcomes in service delivery as a public right (WD, 2004). In relation to MDGs, since environmental protection is the responsibility of government and has serious effects due to the spillover effects, government's invisible hand cannot be detached from solid waste management \& environment as it benefits the community in form of well-being without lessening paybacks (Cointreau-Levine, 1994; Kironde \& Yhdego, 1997; Massoud \& El-Fadel, 2002; Ndandiko, 2010; Oduro-Kwarteng, 2011; WD, 2004). The well-being of the community in solid waste is derived from public cleanliness and safe waste disposal that are vital in public health and protection of the environment (Cointreau-Levine, 1994). Hence this calls for provision communal and central disposal units like skips (garbage containers) without charges fees.

Due to people's attitude on waste management, many companies failed to survive the test of time. In Kampala residents think it is government responsibility to collect and dispose waste in lieu of taxes that they pay to KCCA. This, coupled with the nature of waste privatization, led to closure of the Kitezi Sanitary Landfill since the NEMA report showed that KCCA is the biggest polluter of environment in Uganda owing to its failure to manage the landfill in a sustainable manner. Therefore the concept of sustainability in waste management in Uganda draws from 1996 when Kitezi landfill was commissioned by World Bank. However the landfill turned into an environment polluter, a threat to people's health since the contractor OTADA had failed to execute his duties as per contract, a crisis theory termed as "principle - agent theory" (Ross, 1973). This theory requires that the agent should execute his duties according to the principle by providing services as stipulated in the contract which was not the case, hence forcing KCCA to terminate the contract. Currently the landfill is being managed by government under KCCA and some achievements have been realized since the contract was terminated i.e.;

- $\quad$ South-Eastern Tipping Front had been successfully extended

- Southern Tipping Front had been successfully extended

- Soft areas within Southern Tipping Front have been relatively reinforced

The two tipping fronts - Southern \& South-Eastern were the planned tipping areas for the month of October 2013, as landscaping for developing further North-Eastern access road and accompanied radiations was 
Sustainable Management of KCCA Mpererwe Landfill: History, present, future possibilities ....

being undertaken. The above Constructions helped to refine the radiance of Mpererwe Landfill. It was a respite that garbage trucks can still swiftly deposit garbage at the planned tipping fronts for eventual handling by the Landfill Work-force.

Figures showing the Southern and South-East tipping fronts at Kitezi Landfill

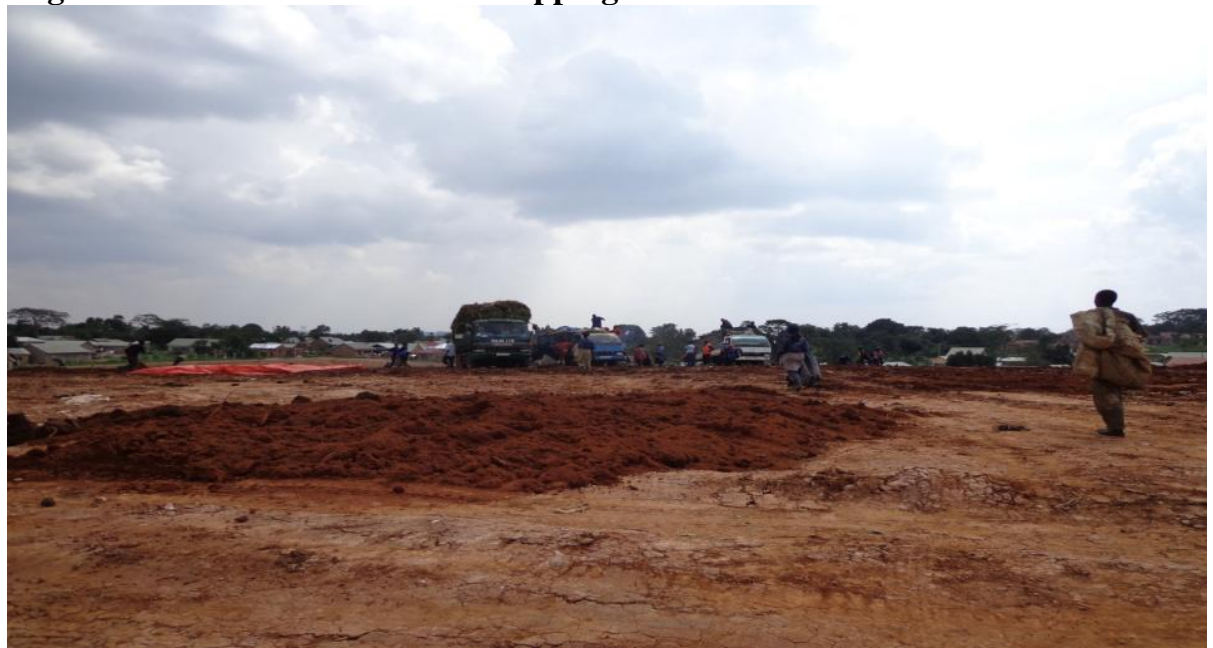

Utilisation of the Southern Tipping Front after marruming $26^{\text {th }}$ September 2013

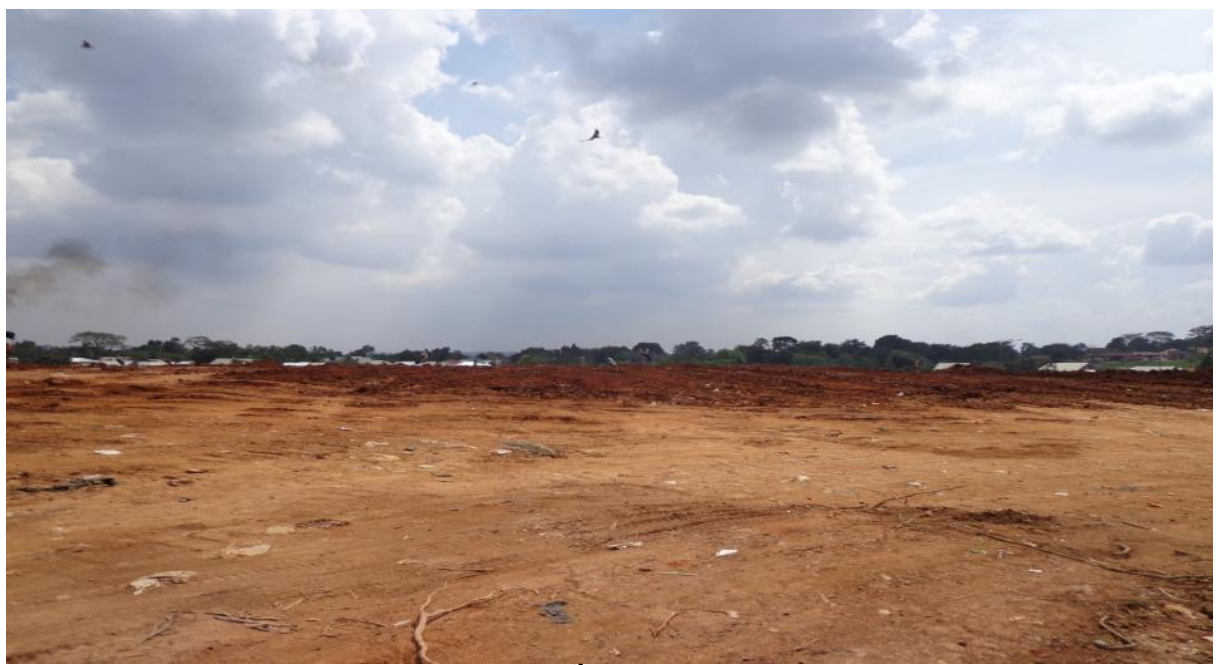

Developing of the South-Eastern Tipping Front $27^{\text {th }}$ September 2013

\section{Current state of shared solid waste management in KCCA}

Municipal waste management systems in the divisions of KCCA originated with the decentralized system until 2009, when waste management efficiency was as low as $45 \%$ of the total generated waste. To date KCCA generates 350,975.38 tonnes annually with the composition of the whole waste flow being $73.80 \%$ vegetable matter, $8 \%$ tree cutting, $5.50 \%$ street debris, $5.50 \%$ paper, $3.10 \%$ metal, $1.70 \%$ saw dust, $1.60 \%$ plastic and 0.90 glass. Glass had the lowest composition while vegetable matter had highest. However, out of the total generated waste, only $55 \%$ is successfully dumped to the landfill in Kitezi while $45 \%$ remains improperly managed.

\section{Methodology}

Due to the traditional nature of waste management in Uganda, data was collected for a period of one year, from the land fill at Kitezi. Three research assistants worked with the researcher to register on a daily basis all refuse trucks that bring in municipal waste for dumping. This was done since the weigh bridge is faulty. Different refuse trucks were categorized in terms of estimated tonnes. To carry out this estimation, the acting landfill manager retrieved data from her archieve. Since the landfill is operational 24 hours, a research assistant was stationed for night duty to capture tonnes from refuse trucks that dump waste at night since so many private operators prefer night shift dumping due to reduced traffic. Data was processed using Micro Excel 2013 for verification and processing. Also interviews were carried out among management staff at the landfill, 
Sustainable Management of KCCA Mpererwe Landfill: History, present, future possibilities ....

KCCA,NEMA and composition plants in Mukono , Jinja, Mbale, Soroti, Lira, Mbarara, Kasese, Kabale, Fortportal, Masindi and Busia, Hoima, Mityana, Entebbe, Gulu, Tororo, Hoima, Masindi and Arua to acertain the history, present, future possibilities and solutions sustainable landfill management in Uganda.

\section{Contextual Solid Waste Management Acts}

The Urban Authority Act of 1964, the Public Health Act 1964 and Local government Act 1997 all define the role of urban local authorities in solid waste management. All the Acts assigned the responsibility of waste management to local councils and assigned responsibilities and roles at every level, they were also supposed to be empowered to take lawful measures to safeguard the environment, uphold public health through keeping the city clean throughout the year and avoid occurrences of nuisance.

In $2000 \mathrm{KCC}$ enacted the law on solid waste management commonly known as the KCC Solid Waste Management Ordinance 2000 (KCC, 2000). The Ordinance has all guidelines concerned with solid waste management in Kampala. It was amended in 2002 and 2006 respectively to cater for KCCA's responsibility to transport and dispose of waste. Section 5 (1) of the ordinance, states that, it is criminal to litter waste, on public or private property, street, in a trench, channel, park, pond, stream, lake, river and that the business owners in commercial buildings are accountable for their waste until a private agent or KCC would come to collect the garbage. In 1999 the National environmental (waste management) regulations were enacted and strictly recommended separation of hazardous from non-hazardous waste in accordance to methods prescribed under sub-regulation section 5.

World Bank and NEMA initiated a project under Environmental Management and Capacity Building Project to provide Municipal Solid Waste Compositing Plants (MSWCP) in 2005 for which nine districts benefited i.e., Mukono, Jinja, Mbale, Soroti, Lira, Mbarara, Kasese, Kabale, and FortPortal. Using lessons learnt from the first project, in 2012, other composting plants were constructed in Hoima, Masindi, and Arua and these were commissioned with skip lifters, (garbage trucks) skips (garbage containers) and wheel loaders after training of municipal staff. (NEMA, 2014). The aim was to enhance high quality solid waste management in all municipalities in Uganda through best practices as well as sustainability of environment.

Table 1.2 Classification of Landfill and Compost plants in Uganda

\begin{tabular}{|l|l|}
\hline Landfill class & Available facilities \\
\hline I Kitezi Sanitary Landfill & $\begin{array}{l}\text { Some Infrastructure i.e., Administrative office, Laboratory, Leachate Treatment Plant, fence } \\
\text { and sorting at landfill. }\end{array}$ \\
\hline $\begin{array}{l}\text { 11 Mukono, Jinja, Mbale, } \\
\text { Soroti, Lira, Mbarara, }\end{array}$ & Small in size, fenced, sorting on site and composting plant \\
Kasese, Kabale, Fortportal, \\
Masindi and Busia
\end{tabular}

There is only one landfill in Uganda. However quite a number of compost plants exist in different districts in Uganda and they were constructed in phases i.e., phase I involved a sanitary landfill for the capital city, phase 11 small size compositing sites and using lessons learnt, phase III is more sound, since the composting sites are big in size, roof trusses are made from steel, a big administrative block within which the staff have provision for wash and changing rooms.

\section{Future projections for landfills in Uganda Charges imposed for waste management services}

The solid waste ordinance 2000 (KCC, 2000) Section 19 specified that council shall prescribe fees for collection and final disposal. This prompted private companies to initiate charges. However the attitude of people is still very poor since they believe that they pay enough taxes to government and therefore it is the responsibility of government/local government to collect waste. This in turn encourages indiscriminate waste disposal habits among the residents to avoid payment. Secondly, the majority of residents in Kampala live in the slums and are poor with no permanent and owned residences hence challenges in storage of waste. At Kitezi sanitary landfill, whereas dumping of waste is free of charge, the weigh bridge is faulty and this poses a challenge in maintaining the site to the required sustainable standards of public health and environmental conservation.

\section{Sources of separation and recycling}

Application of waste separation at the source (sorting) is not in existence and has not taken shape in Uganda though the Ordinance provides for it. The separation allows recovery and subsequently reduces on the total amount of waste disposed off (Fauziah and Agamuthu, 2012). It also adds value (Nzeadibe \& Ajaero, 2010; Scheinberg, 2011; Wilson, Araba, Chinwah, \& Cheeseman, 2009). Such practices give a country's 
dumping site a longer life. Additionally although private firms have not been given the total mandate in the management of solid waste, scavenging informal recycling is not illegal since it turns out to be a good source of income to many Ugandans who are searching jobs in congested job market. However, any small firm that ventures into waste recycling business is required to register free of charge as a Community Based Organization at the division or as a private making organization with KCCA. This enables the firm to pay for the necessary licenses that award permission to formal operations.

Table: 3. Appraised Number of dumping sites in Uganda

\begin{tabular}{|l|l|}
\hline Status of dumping sites & Current Quantity \\
\hline Landfill & 1 \\
\hline compost plants & 19 \\
\hline Total & 20 \\
\hline
\end{tabular}

Table: 4 Sanitary landfill and Dumping sites in Uganda in 2013

\begin{tabular}{|l|l|l|}
\hline Name of composting plant and sanitary land fill and location & Status of dumping facilities & Inauguration date \\
\hline Lweza dumping site & Closed & 1975 \\
\hline Lubigi dumping site & Closed & 1982 \\
\hline Kitezi Sanitary Landfill & Functioning & 1996 \\
\hline Mukono dumping site & Functioning & 2005 \\
\hline Jinja dumping site & Functioning & 2005 \\
\hline Mbale dumping site & Functioning & 2005 \\
\hline Soroti dumping site & Functioning & 2005 \\
\hline Lira dumping site & Functioning & 2005 \\
\hline Mbarara dumping site & Functioning & 2005 \\
\hline Kasese dumping site & Functioning & 2005 \\
\hline Kabale dumping site & Functioning & 2005 \\
\hline FortPortal dumping site & Functioning & 2005 \\
\hline Masindi dumping site & Functioning & 2012 \\
\hline Busia dumping site & Functioning & 2012 \\
\hline Hoima dumping site & Functioning & 2012 \\
\hline Mityana dumping site & Functioning & 2012 \\
\hline Entebbe dumping site & Functioning & 2012 \\
\hline Gulu dumping site & Functioning & 2012 \\
\hline Tororo dumping site & Functioning & 2012 \\
\hline Hoima, dumping site & Functioning & 2012 \\
\hline Masindi dumping site & Functioning & 2012 \\
\hline Arua dumping site & Functioning & 2012 \\
\hline
\end{tabular}

\section{Concerns on illegal dumping}

The ordinance offers a permissible outline for the procedures of private sector service area providers in waste management, levying service charges to the populace of Kampala. KCCA is mandated through its private approved agents to warrant that garbage is appropriately disposed in an acceptable manner to meet the requirements of public health and environmental conservation. However, implementation of the guidelines have been tested with disciplinary actions. i.e, a person disregarding sections of the solid waste management regulations is only accountable to be sentenced to detention for a period of not beyond six months or to pay a fine more than 300,000 shillings (\$107) or less than 60,000 shillings (\$21.4). These consequences do not enhance or overhaul the status of solid waste management and its regulations.

In order to implement the waste management ordinance, individuals caught illegally dumping waste are taken to Legal department KCCA City Hall Court where files are prepared and later forwarded to the charge office. However, how much each culprit pays depends entirely on the judge. Furthermore, where the culprits are not forwarded to charge office, they are given community work in the area where the offence is committed. The processes and procedures of implementing the legal instruments are totally subjective on where the offence is committed, who caught the person in the act and his willingness to take action. The ordinance is envisioned to dishearten scattering and unlawful dumping and consequently lessen the service provider's need to dedicate resources to uphold clean surroundings in the society.

\section{Decisive power on waste management facilities}

The ordinance empowers KCCA to adopt appropriate plans to control solid waste and public sanitation administration. This comprises of the preparation and forecasting of the suitable location site, planned scope and form of landfill deliberated for local landscape, land use, planned final elevation and outlines, access roads, penetration of ground water, vicinity to surface water and any extra data needed by council. This will enable KCCA to plan for developments in the management of waste infrastructure as advanced equipment develop overtime. 
Additionally, section 34-35 part (i) of the ordinance (KCC, 2000) also contains articles linked to the landfill operation, in terms of providing an access road to the location: a not-permanent all season paths on the landfill site labelled with suitable guiding symbols were obligatory; a truck turn around to ease the arranged programme of trucks and dumping of solid waste; take all essential measures as well as the creation of physical obstacles to stop garbage from being blown by the wind; take all responsible actions needed to stop or remove the breeding of flies, mosquitoes and extra insects, rodents or vermin that could danger public health; avoid and regulate fires or pollution of smoke fumes, air by dustand surface underground water and; eliminate any public nuisance on the premises.

\section{Closing landfills}

Additionally, two dumping sites were closed i.e., Lweza and Lubigi in 1996 after opening up a new sanitary landfill in Kitezi. Currently the landfill is the only sanitary landfill in the country while others are just dumping sites with composting plants. However the Landfill Laboratory and Control Room were closed ahead of renovations since they were in a sorry state and other landfill infrastructure including leachate treatment plant, weighbridge, gate and buildings need to be replaced.

Traditional ways of management waste in Uganda resulted into absolute lack of a data base of dumping sites, over stayed backlogs, illegal dumping sites and absence of government recycling plants in Uganda lack of elementary data is a weakness inappropriate arrangement for forthcoming development plans for any country.

\section{Licensing Provision}

The ordinance did not specify on authorizing establishment, there is no section specifying compulsory fixed license for private service providers. Section 37 part (i) explains with ambiguity that KCCA prescribes fees to be paid for removal and final disposal of waste. The fees prescribed under subsection (i) may be paid either to KCCA or the licensed agents or collectors and fees prescribed under this section may be annual or periodic and shall be set at an amount not exceeding costs required for planning, capital and operating costs of solid waste collection, storage and disposal. Under section 40, the ordinance requires provider of solid waste management services to obtain a license from KCCA and KCCA and accompanied by prescribed fees and failure to comply, of which will cause rejection of permit cancelation. This is reflected as a significant section of the Ordinance since the present waste management permit owners have shown no commitment and readiness to enhance or advance waste management process in their jurisdiction. In addition, KCCA has partnered with World Bank to get a suitable private company with suitable facilities making it possible for landfill gas collection a potential type of project for which funding may be available. Similarly, there is currently an ongoing project with World Bank for building composting plants in the different dumping sites in different districts in the country, which is a step ahead in the right direction of sustainable landfill management in Uganda.

\section{Conclusion}

In the past, waste management practices in Uganda were relatively traditional branded by undesired backlog heaps of waste for decades, exposed and common burning of garbage heaps within Kampala. This intolerable condition triggered the necessity for enhancements of the nation's waste management arrangements, most importantly, as waste production increased quickly and the structure of waste turned to be more complex.

Contemporary attitude and activities disclose a slight enhancement through improved collection efficiency, continued maintenance of the landfill by KCCA and cancelation of contract services at the landfill, clearing the backlogs in the town areas as well as certain levels of environment security procedures. In some districts more composting plants have been constructed by World Bank. The transformations remain through sharing solid waste management among the five divisions by sharing refuse trucks, causal workers and landfill to ensure that they eliminate the uncollected waste in the city. The Solid Waste Ordinance 2000 and the National environmental (waste management) regulations aim to enhance attitude change by eliminating indiscriminate and illegal disposal and promoting the best practices as well as sustainability of environment including the sanitary landfill.

The projected future of waste management in Uganda appears to be positive as the policy alternations in KCCA administration focus on sanitation and beautification of Kampala to match other cities in world. Both implementers and the community are largely not aware of this ordinance and there is need to translate it and disseminate to the public. The outdated KCCA ordinance is weak to meet the expectations of public and yet it was envisioned that change of policy and strategies will improve service delivery. This coupled with private companies dumping waste free of charge, poses a big challenge in the maintaining a sustainable landfill for Uganda. Thus levying charges to private companies for disposing waste is inevitable and the Ordnance should be amended to incorporate sustainability if the landfill is to be maintained. This coupled with government allocation of funds according to percentage generation of waste in KCCA, emphasis on reduction of waste 
generation by ensuring sustainable reuse and recycling as well as addressing key success factors including expertise, awareness of the public, strengthening partnerships to pool resources and promoting advanced technology will help Uganda achieve sustainable management of Kitezi landfill (Madinah, 2014).

\section{References}

[1]. Adewale, M. T. (2011). Composting as a Sustainable Waste Management Technique in Devel-

[2]. loping Countries. Journal of Environmental Science and Technology, 4 (2), 93-102. doi: DOI: 10.3923

[3]. Agamuthu, P., Khidzir, K., \& Hamid, F. S. (2009). Drivers of sustainable waste management in Asia. Waste Management \& Research.

[4]. Ahmed, S. A., \& Ali, S. M. (2006). People as partners: Facilitating people's participation in public-private partnerships for solid waste management. Habitat International, 30(4), 781-796.

[5]. Batley, R. (2001). Public-private partnerships for urban services. The challenge of urban government: Policies and practices, 199214

[6]. Baud, I., Post, J., \& Furedy, C. (2004). Solid waste management and recycling: actors, partnerships and policies in Hyderabad, India and Nairobi, Kenya (Vol. 76): Springer.

[7]. Cointreau-Levine, S. (1994). Private sector participation in municipal solid waste services in developing countries (Vol. 1): Urban Management Programme.

[8]. Fauziah S.H., A., P. and Goh, K.W. . (2005). River water pollution by municipal landfill leachate, In Malaysia. Proceedings of the 1st IWA-ASPIRE Conference, Singapore, 1-8.

[9]. Fauziah, S. H., \& Agamuthu, P. (2012). Trends in sustainable landfilling in Malaysia, a developing country. Waste Management \& Research, 30(7), 656-663. doi: 10.1177/0734242x12437564

[10]. Government, U. (2013). Statement of issues in Kamapala Capital City Authority GoU.

[11]. Hamer, G. (2003). Solid waste treatment and disposal: effects on public health and environmental safety. Biotechnology Advances, 22(1), 71-79.

[12]. Hood, C. (1991). A public management for all seasons? Public Administration, 69(1), 3-19.

[13]. Hood, C. (1995). The "New Public Management" in the 1980s: variations on a theme. Accounting, organizations and society, 20(2), 93-109.

[14]. Kassim, M. S. (2006). "Sustainability of Private Sector in Solid Waste Collection: A Case of Dar- es-Salaam Tanzania." A Doctoral Thesis in partial fulfilment for the requirements for the award of the Doctor of Philosophy. Loughborough University.

[15]. KCC, K. C. C. (2000). Solid Waste Management Ordinance 2000. Uganda, 1(1), 18.

[16]. KCCA, K. C. C. A. (2013). http://www.kcca.go.ug/services.php\#waste_management.

[17]. Kironde, J., \& Yhdego, M. (1997). The governance of waste management in urban Tanzania: towards a community based approach. Resources, conservation and recycling, 21(4), 213-226.

[18]. Lou, X., \& Nair, J. (2009). The impact of landfilling and composting on greenhouse gas emissions-a review. Bioresource Technology, 100(16), 3792-3798.

[19]. Madinah, N., Boerhannoeddin, A., \& Binti Raja Ariffin, R. N. . (2014). Division Solid Waste Generation and Composition in Kampala Capital City Authority, Uganda: Trends and Management. . IOSR Journal of Environmental Science, Toxicology and Food Technology (IOSR-JESTFT), 8(10), 57-62. doi: 10.9790/2402-081035762

[20]. Massoud, M. a., \& El-Fadel, M. (2002). Public-private partnerships for solid waste management services. Environmental Management, 30(5), 0621-0630.

[21]. Mugagga, F. (2006). The Public-Private Sector Approach to Municipal Solid Waste Management: How does it Work in Makindye Division, Kampala District, Uganda?

[22]. Mwiganga, M., \& Kansiime, F. (2005). The impact of Mpererwe landfill in Kampala-Uganda, on the surrounding environment. Physics and Chemistry of the Earth, Parts A/B/C, 30(11), 744-750.

[23]. NBS, B. R. (2013). Workers at the Kitezi Waste landfill complain of neglect. NBS Television read article.

[24]. Ndandiko, C. (2010). Private provision of public services in developing countries. University of Twente

[25]. NEMA. (2014). World Bank Project on composting plants in Northern Uganda; (http://www.nemaug.org/ on 21.06.2014). Uganda.

[26]. NEMA, G. T. (2005). Kitezi Site a Death Trap. New Vision the Uganda's Leading Daily.

[27]. Nguyen, P. T., Yasuhiro, M., and Takeshi, F. . (2011). Assessment of plastic waste generation and

[28]. its potential recycling of household solid waste in Can Tho City, Vietnam. Environ-mental Monitoring and Assessment, 175, 23-35.

[29]. Nzeadibe, T. C., \& Ajaero, C. K. (2010). Informal waste recycling and urban governance in Nigeria: Some experiences and policy implications. Handbook of environmental policy, 245-264.

[30]. Oduro-Kwarteng, S. (2011). Private Sector Involvement in Urban Solid Waste Collection: UNESCO-IHE PhD Thesis: CRC Press.

[31]. Post, J. (2004). Evolving Partnerships in the Collection of Urban Solid Waste in the Developing World. In "Solid Waste Management and Recycling; Actors, Partnerships and Policies in Hyderabad, India and Nairobi, Kenya.”. Baud, I., Johan, P., Christine F., Eds., GeoLibraries Series, Kluwer Academic Publishers, Dordrecht.(76), 21-36

[32]. Rabinovitch, J. (1997). Urban problems remain similar world wide - unemployment and insufficient solid waste disposal are main concerns. Paper presented at the International colloquium of Mayors at the international conference on governance for sustainable growth and equity.

[33]. Ross, S. A. (1973). The economic theory of agency: The principal's problem. The American Economic Review, 134-139.

[34]. Scheinberg, A. (2011). Value added: modes of sustainable recycling in the modernisation of waste management systems: publisher not identified.

[35]. Scott, J., Beydoun, D., Amal, R., Low, G., \& Cattle, J. (2005). Landfill management, leachate generation, and leach testing of solid wastes in Australia and overseas. Critical Reviews in Environmental Science and Technology, 35(3), 239-332.

[36]. Tukahirwa, J. T., Mol, A. P., \& Oosterveer, P. (2010). Civil society participation in urban sanitation and solid waste management in Uganda. Local Environment, 15(1), 1-14.

[37]. UBOS, G. o. U. (1990). Uganda Population Census Main Report Uganda.

[38]. Uganda, N. E. M. A. G. o. (2011). State of Environment Report 2011. Environment Uganda

[39]. UNEP, U. N. E. P. (2011). Waste - Investing in energy and resource efficiency. Towards a green economy 44

[40]. WD, W. D. (2004). World Development Report

[41]. West, E. G. (1976). Adam Smith's economics of politics. History of Political Economy, 8(4), 515-539.

[42]. Wilson, D. C., Araba, A. O., Chinwah, K., \& Cheeseman, C. R. (2009). Building recycling rates through the informal sector. Waste Management, 29(2), 629-635. 